usefully employed by caring for those patients who need them than by routine visits to all old people.

London, S.W.17.

G. S. Plaut.

\section{SATELLITED CHROMOSOMES}

SIR,-Early reports on the characteristics of human chromosomes described only two pairs of acrocentric chromosomes as having satellite bodies on the short arms. ${ }^{1-3}$ The Human Chromosome Study Group ${ }^{4}$ accepted the existence of three satellited pairs of autosomes. Ferguson-Smith and Handmaker ${ }^{5}$ presented evidence that all acrocentric pairs of chromosomes were satellited. Gromults and Hirschhorn ${ }^{6}$ stated that, although Ferguson-Smith et al. had demonstrated nine satellited chromosomes in a karyotype reproduction in their paper, they had not mentioned the total number of observed satellites in any one cell, and in a later report stated that they had never seen ten chromosomes with distinct chromatin knobs in any one diploid cell. Gromults and Hirschhorn added that they had evidence that all ten acrocentric chromosomes in one diploid cell could, in fact, have satellite bodies.

We should like to present evidence in support of the observations of Gromultz and Hirschhorn. In the following case all chromosomes from groups 13-15, 21, and 22 are satellited.

The patient, a 29-year-old man with thyrotoxicosis, was treated with $8 \mathrm{mC}$ of radioactive iodine on Sept. 5, 1963. Three leucocyte cultures were made according to the technique of Moorhead et al. ${ }^{7}$-one before treatment and two after treatment. Of these, the first was 24 hours after treatment, and the second 5 days after treatment. Both cultures showed tetraploid cells. A total of 300 cells were scanned (100 cells from each culture). $11 \%$ of the metaphases showed all ten acrocentric satellited chromosomes in diploid cells. Figs. 1 and 2 show a diploid Giemsa-stained cell in metaphase and its karyotype with arrows directed to the acrocentric satellite. Satellited chromosomes are defined as those showing a secondary constriction with distinct chromatin knobs projected from the arms on slender stalks, and these show clear evidence of negative heteropyknosis at the ends of the chromosome arms. This 1. Tiio, J. H., Puck, T. T. Proc. nat. Acad. Sci., Wash. 1958, 44, 1229. 2. Chu, E. H. Y., Giles, N. H. Amer. F. hum. Genet. 1959, 11, 63. 3. Levan, A., Hsu, T. C. Hereditas, 1959, 45, 665.

4. Human Chromosome Study Group. F. Hered. 1960, 51, 214.

5. Ferguson-Smith, M. A., Handmaker, S. D. Lancet, 1961, i, 638

6. Gromults, J., Hirschhorn, K. ibid. 1962, ii, 54

Moorhead, P. S., Nowell, P. C., Mellman, W. J., Battips, D. M., Hungerford, D. A. Exp. Cell Res. 1960, 20,613.

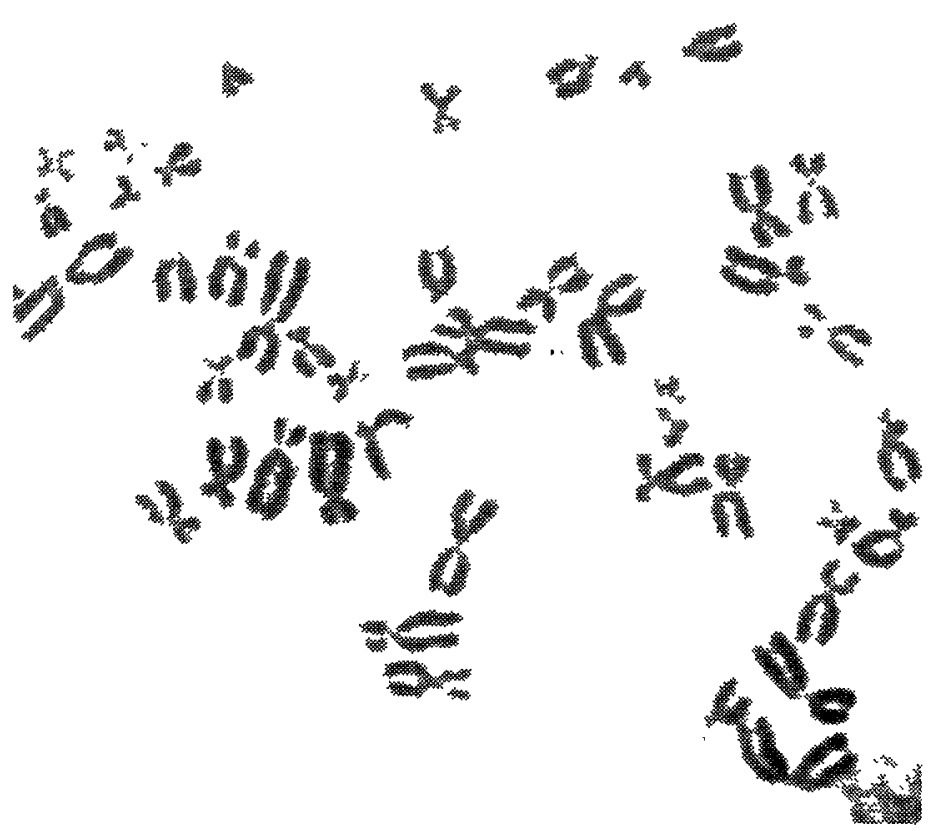

Fig. 1-Diploid cell in metaphase (Giemsa).

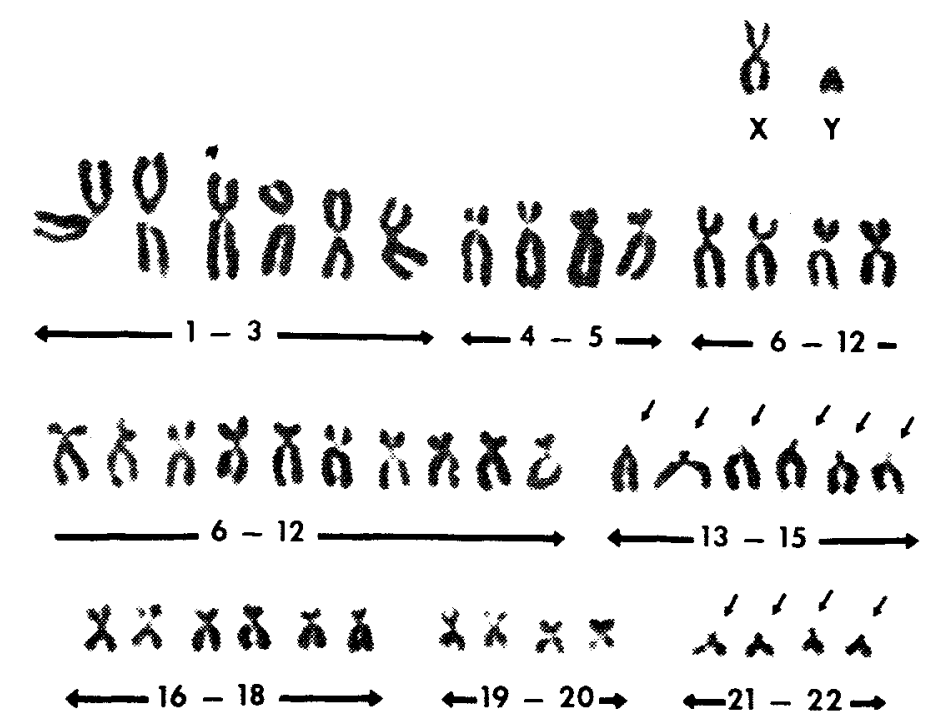

Fig. 2-Karyotype of cell : arrows point to acrocentric satellite.

definition accords with that of Ferguson-Smith and Handmaker. ${ }^{5}$

From these findings and accumulated observations from a survey, currently in progress, of chromosomal damage by radioisotopes and anti-tumour agents, we conclude that the number of satellited acrocentric chromosomes in man varies. The number may vary from 4 to 10 and does not reflect phenotypic abnormality. We do not know whether these are inherited variations or not. In the case described here, karyotypes of the patients cultured leucocytes showed all the acrocentric pairs satellited.
Yeterans Administration Hospital and University of Michigan School of Dentistry
Ann Arbor, Michigan, U..S.A.

Carlos E. Nasjleti

Charles T. KNORPP JEROME J. HINIKER.

\section{MACROMETHOD FOR CULTURING LEUCOCYTES FOR CHROMOSOMAL ANALYSIS}

SIR,-Since the reports of techniques for culturing leucocytes for chromosomal analysis by Hungerford et al. ${ }^{8}$ and Moorhead et al. ${ }^{9}$ the general trend has been towards evolving simpler techniques which will still produce good metaphase plates. After experimentation with various modifications of the original techniques and with various media, the following simplified technique, which produces very good results, has been developed for use with human peripheral venous blood.

\section{Method}

1. $10 \mathrm{ml}$. of blood is withdrawn from a vein with a syringe and needle. The needle is discarded and the blood discharged into an Evans Medical heparinised tube, the mouth of which is flamed before and after injecting the blood. Gentle shaking mixes the blood with the dried heparin film and prevents clotting.

2. The blood is allowed to stand for about $1 \frac{1}{2}$ hours to separate the red blood-cells by simple precipitation.

3. The supernatant fluid containing white blood-cells is drawn off by a Pasteur pipette, and introduced into a sterile culture bottle. Approximately $5 \mathrm{ml}$. of T.C. medium 199 (Glaxo) is added, followed by three drops from a Pasteur pipette of phytohæmaglutinin P (Difco) (approximately 0.25 $\mathrm{ml}$.). The culture is shaken and incubated at $37 \mathrm{C}$ for 70 hours. It is shaken gently three times daily during culture to break up any clumps of cells. This produces a better growth of cells than is obtained by leaving the cultures undisturbed. 'Colcemid' $(0.001 \%)$ is added in the proportion of $0.1 \mathrm{ml}$. per $\mathrm{ml}$.

8. Hungerford, D. A., Donnelly, A. J., Nowell, P. C., Beck, S. Amer. F. hum. Genet. 1959, 11, 215.
9. Woorhead, P. S., Nowell, P. W., Mellman, W. J., Battips, D. M.. Moorhead, P. S., Nowell, P. W., Mellman, W. J
Hungerford, D. A. Exp. Cell. Res. $1960,20,613$. 